Article

\title{
Environmental Constitutionalism in Latin America
}

\author{
Ahmad Shohani ${ }^{1, *(D)}$, Elham Ataei ${ }^{1}\left(\right.$, Nima Norouzi ${ }^{2}(\mathcal{C}$ \\ ${ }^{1}$ School of political science and international relationships, Payam Noor University, Tehran, Iran \\ ${ }^{2}$ School of Law, Department of Human Sciences, Islamic Azad University, Tehran, Iran \\ ${ }^{*}$ Correspondence: Ashohani1300@gmail.com
}

How to cite this paper: Shohani, A., Ataei, E., \& Norouzi, N. (2021). Environmental Constitutionalism in

Latin America. Universal Journal of Social Sciences and Humanities, 1(1), 54-66. Retrieved from https://www.scipublications.com/journal/index.php/ujssh/article/view/96

\section{Received: July 29, 2021}

Accepted: September 1, 2021

Published: September 2, 2021

Copyright: (c) 2021 by the authors. Submitted for possible open access publication under the Creative Commons Attribution (CC BY) license

(http://creativecommons.org/licenses /by/4.0/).

\begin{abstract}
Chile is part of the phenomenon of Environmental Constitutionalism developed in the Latin American region. Thus its Political Constitution contemplates the right of people to live in an environment free of contamination and establishes duties for the state regarding the law and the protection of the environment. However, this formula has been deficient, which warrants rethinking the issues related to the environment at the constitutional level. This work follows this path from the study of the constitutional reform projects currently in the National Congress to systematize analysis at the service of a change that is the basis for an adequate environmental legal framework, respectful of human rights human beings and that maximizes the protection of the environment.
\end{abstract}

Keywords: Green Constitution; Strong sustainability; Green Law; Natural Balance.

\section{Introduction}

Unlike other countries in the Latin American region, Chile has one of the oldest constitutional texts and has suffered few modifications, even less in the treatment of the environment. In recent years, one of the central themes in Chilean society has been a constitutional change for Chile, openly debated by academia and the political world, and has become a demand of the different social movements.

The formula for the environmental issue in the current Constitution has been insufficient. From there arises the need to discuss how a new Constitution should be considered, a text that solves the problems already known, addresses the challenges of the 21st century, and adjusts to environmental standards that provide greater well-being to the inhabitants of Chile.

Environmental conflicts in Chile have been diverse, and in recent years, they have become more evident. Even though progress has been made in creating a new institutional framework in the matter, [1] this work is based on the premise that many of the pending challenges not only go through the modification or creation of laws, nor through adjustments in the lower levels of the legal system Rather, in the case of Chile, a profound change is required, which must necessarily arise from the Political Constitution of the Republic of Chile.

Based on the above, a brief overview will be made of the evolution of environmental Constitutionalism and its incorporation in Latin America, its reception in Chile will soon be deepened to show some of its shortcomings. Finally, an exploratory methodology will be deepened in the constitutional reform proposals submitted to the National Congress. The main objective is to systematize the analysis of the reform proposals related to the environment $[2,3]$ and to answer whether or not such reforms are sufficient for creating a basic environmental legal framework, respectful of human rights, maximizing environmental protection, and responding to new challenges. Finally, it is hoped that some of the reflections raised here will help guide the discussion around an upcoming constituent debate. 


\section{Environmental Constitutionalism in Latin America}

Today half of the constitutions in the world expressly or implicitly recognize the right to the environment as a fundamental right. However, approximately only a third of them contain procedural provisions applicable to environmental matters in association with the rights to information, participation, and access to environmental justice [1-3]. Much of the present is in Latin America. In this way, to show the constitutional changes related to issues related to the environment, we will begin by taking a panoramic look at the Latin American region.

For Latin Americans, Environmental Constitutionalism is an expression that appears since 1972 as a legal, political phenomenon in which the Constitutions incorporated ideas about the protection of the environment and sustainable development, in line with the importance that the environment acquired at the level. international [4].

The inclusion of environmental regulations in constitutional texts is recent in history [5]. In general, most of the publications related to Environmental Constitutionalism indicate as a key fact the United Nations Conference on the Human Environment (1972), which culminated with the Stockholm Declaration, which marked the beginning of a new stage in the development of Environmental Law at the international level, since for the first time the importance of the environment for man is made clear with broad consensus [6].

The Stockholm Declaration, from an anthropocentric perspective, recognizes the Earth as the home of humanity in the following way: "man has the fundamental right to (...) enjoy adequate living conditions in a quality environment that allows him to lead a dignified life "(Principle 1 of the Stockholm Declaration on the Human Environment, at the United Nations Conference on the Human Environment, 1972).

From there, it is a fact that the Constitutions in Latin America included the environmental issue, starting with Panama (1972), Cuba (1976), Peru (1979), Ecuador (1979), Chile (1980), Honduras (1982), El Salvador (1983), Guatemala (1985), Haiti (1987), Nicaragua (1987), Brazil (1988) and Colombia (1991) [7].

Then, after the United Nations Conference on Environment and Development (1992), the idea of sustainable development was highlighted, stating that "Human beings are at the center of concerns related to sustainable development. They have the right to a healthy and productive life in harmony with nature "(Principle 1, Rio Declaration on Environment and Development, 1992), and thus new States emerged that included environmental provisions, while others were modifying them, such as Paraguay (1992), Peru (1993) Argentina (1994), Dominican Republic (1994), Ecuador (1998) and Venezuela (1999).

Varela (2013) describes how Latin American countries have moved firmly towards a sustainable development law in their Constitutions, through six phases on the constitutionalization of sustainability, describing them in the following order: (1) the one that links the environment with public health, (2) collective environmental rights, (3) individual environmental rights, (4) environment concerning the right to life and its quality, (5), incorporation of sustainable development, (6) Constitutions of the XXI century, in which sustainability is transformed into a right and duty, among which Ecuador (1998), Venezuela (1999), El Salvador (2000) and Uruguay (2004) stand out, and finally, a seventh stage would be forming of strategic environmental assessment at the constitutional level [8].

Today an eighth phase could even be added based on a paradigm shift, as would happen with the biocentric perspective, clearly identified in Ecuador and Bolivia. Both Constitutions are the most recently reformed in Latin America and were the result of constituent assemblies. The Constitution of Ecuador (2008) and that of Bolivia (2009) have innovated with concepts, such as "good living" or "living well" and associated rights, overturning the traditional anthropocentric vision, establishing a new man-nature relationship, by which nature or Pachamama is the subject of rights, and has the right to have its existence respected, to the maintenance of its life cycles, among others. 
As for the Law, the meanings of the right to an environment at the constitutional level are varied. In Argentina and Bolivia, the right to live in a healthy and balanced environment is contemplated. In Brazil, both its National Constitution and each state refer to the right to an ecologically balanced environment. In Colombia, everyone has the right to a healthy and ecologically balanced environment. Paraguay has the right to a healthy environment. In Peru, there is the right to enjoy a balanced and adequate environment to develop people's lives. Although Uruguay does not expressly recognize the law, it declares the protection of the environment of general interest, recognizes it as a legal asset, and integrates it into a national policy. Venezuela establishes an individual and collective right to enjoy life and a safe, healthy, and ecologically balanced environment $[8,9]$.

The evolution of a Right to a healthy or adequate environment with a human rights approach has been incorporated into national legal systems. However, in Latin America, there are particularly relevant common patterns such as the economic pressures suffered by some States, the permanent extraction of natural resources and their limited nature, activities such as mining and logging are increasing, conflicts between large companies and communities persist Added to this are the so-called "sacrifice zones4". Likewise, the effects of climate change are already present and are increasing. All these are some of the problems that strongly threaten the rights of people, and in general, the life of ecosystems.

\section{Reception of the right to the environment in the Chilean Constitution}

The current Political Constitution of the Republic of Chile, better known as the 1980 Constitution, was approved by plebiscite and promulgated during the military regime, entering into force in 1981, and is the first in the history of Chile to incorporate the environmental issue, this It was enshrined in Chapter III: "On Constitutional Rights and Duties." Its article $19 \mathrm{~N}^{\circ} 8$ provides:

The Constitution assures all people: The right to live in a pollution-free environment. The state must ensure that this right is not affected and protect the preservation of nature. The law may establish specific restrictions on exercising certain rights or freedoms to protect the environment (Political Constitution of the Republic of Chile, 2005).

In addition, article 20, second paragraph, provided protection when the indicated right is affected by an arbitrary and illegal act attributable to a specific authority or person.

Such provisions were unharmed for more than 20 years. It was only in 2005 that the Constitution was amended through Law 20,050, introducing modifications to various articles5, among others to article 20, second paragraph, replacing the expression "arbitrary and illegal act" by "illegal act or omission" (Political Constitution of the Republic of Chile, 2005).

\subsection{Consecrated law}

The Constitution does not contemplate a right to the environment itself but rather people to "live" in an environment free of contamination. People are the holders of this right and only those who could be affected. Three perspectives (broad, restrictive6, and eclectic doctrine) have followed the Chilean courts regarding content. However, it has been the broad perspective that has been established in the most recent jurisprudence. In general, the discussion about the content has waned with the publication of Law 19,300 on General Bases of the Environment in 1994, since key concepts were established, these are the environment 8 and the pollution-free environment, among others.

The broad perspective considers the environment in two senses, one as an ecosystem or in terms of the variety of elements that make it up [9]. The negative of this vision is that it expands the area of influence of the law, and with it, some argue that the environment is everything, and at the same time nothing, given the impossibility of particularizing each element that makes it up. 
Ultimately, Article $19 \mathrm{~N}^{\circ}$, which claims that people can live in a pollution-free environment, would be a commitment that the Constitution could not ensure $[9,10]$ and that, according to its legal definition, it is

that in which the pollutants are in concentrations and periods lower than those likely to constitute a risk to the health of people, the quality of life of the population, the preservation of nature, or the conservation of environmental heritage (Law 19,300, 1994, art. 2, letter $\mathrm{m}$.).

The disadvantage of the concept lies in: first, because of the scientific uncertainty of the risk or damage, it has been estimated that certain substances do not violate the guarantee; secondly, the same has happened because certain levels of pollutants are not stipulated by regulation; And, finally, it must be understood that sometimes the law could not only be affected by pollutants but also due to being overexploited environments.

\subsection{Duties of the State concerning the environment}

Regarding the generic duties imposed by the norm of article 19 No. 8 to the State of Chile is to ensure that the right to live in an environment free of contamination is not violated, for which people are endowed with the action contemplated in article 20 subsection 2; and the duty to protect the preservation of nature. To the previous two, a third duty of the state is added, to protect the environment, independently of fundamental rights. All these would be framed according to Galdámez in what is known as the precautionary and landscape protection principle, although in reality, they are only implicitly present $[11,12]$.

It is even implicitly possible to give rise to a fourth duty of the state if the constitutional mandate of Article 1, paragraph 4 of the Constitution, by which the state must give security to its population, which could be extended according to Garrote to environmental safety, so as not to put people's survival and quality of life at risk.

Now, following the Law of General Bases of the Environment, "preserving" is understood as the set of policies, plans, programs, norms, and actions destined to ensure the maintenance of the conditions that make the evolution and development of species possible and of the country's ecosystems (Law 19,300, 1994, art. 2, letter p.), which has generally been translated into the basis for the declaration of new protected areas or species, and not in duty to seek environmental prevention damage, or in cases of damage, tend to repair it.

In turn, the law defines "conserving environmental heritage" as the rational use and exploitation or repair, where appropriate, of the components of the environment, especially those of the country that are unique, scarce, or representative, to ensure its permanence and its capacity for regeneration. In this way, it is confirmed that the duty to preserve would not be aimed at prevention and repair. Otherwise, the State of Chile should "protect" because plans and programs are carried out to maintain ecosystems.

\subsection{Environmental protection resource}

Some time ago, an attempt was made to reform subsection 2 of article 20 to eliminate the " $\mathrm{e}$ " between arbitrary and illegal, and thus avoid a double requirement to admit the protection action, but this did not happen, since after the reform by Law $\mathrm{N}^{\circ} 20,050$ of 2005, the word arbitrary was eliminated. This, for Soto Kloss (2007), is "an ineptitude of proportions, which even contradicts the very meaning of what is to pollute" [13], hindering the possibility of filing a protection appeal since it would only proceed in the face of illegalities.

As a result of the preceding, the classical jurisprudential criteria have been insufficient to resolve the cases of projects subject to environmental authorization, in terms of the illegality that gives rise to the appeal, since it must be sufficiently serious and of an 
exceptionality that deserves to reestablish the empire of the right to replace the Environmental Courts 9. Today the latter, created by Law 20,600 of 2012, is in charge of resolving disputes about environmental qualification resolutions issued by the competent authority, which suffer from the vice of illegality.

In this sense, regarding the origin of the protection appeal in the case of decisions issued by the Chilean environmental authority, the Supreme Court has been emphatic, stating that the filing of the protection appeal is without prejudice to the other rights that may be asserted Before the competent authority or courts, it cannot be overlooked that after the enactment of Law 20,600 (2012), which created the Environmental Courts, these are the ones called to hear the environmental disputes under their jurisdiction (Mayor of Calera de Tango with the Environmental Assessment Service, 2018, Considering 12), arguing that such disputes must be resolved at the headquarters of the new institutionality so that the protection recourse filed in the Courts of Appeals has been limited.

On the other hand, it must be recognized that, since natural persons are those affected by a violation of 19 No. 8, only they could resort to protection action, since they, that is, men and women, are the owners11, although in practice they are It has allowed both natural and legal persons to appeal for protection.

Although before there was discussion regarding the ownership of the resource [13, 14], today the Supreme Court has held that "the trend of comparative law is the overcoming of the individualistic view of the legitimizing interest, a circumstance that is especially sensitive in matters such as protection of the environment, and others." In this regard, he explains that ownership "does not correspond to a single citizen, but must be attributed to a community as a whole" (Sociedad Química y Minera de Chile SA with the Environmental Assessment Commission of the Tarapacá Region, 2015). In this way, the broadening of the meaning and scope of ownership of provision 19 No. 8 and its protective action is observed.

Likewise, it is argued that the right contemplated in article 19 No. 8 is a Human Right of a collective nature, of a third-generation that protects diffuse interests, and that it would correspond to all people or the community [15]. The preceding does not imply that it cannot coexist with individual interests. Thus, they can be exercised individually, although their collective defense would be more convenient13.

\subsection{Restrictions on other rights}

It happens that the right recognized in article 19 No. 8 collides, not infrequently, with the property right (19 No. 24) and the right to develop any economic activity (19 No. 21). And although the Constitution establishes that by law, specific restrictions may be established on the exercise of certain rights or freedoms to protect the environment, it states in its article 19 No. 26 that rights cannot be affected in their essence, nor impose conditions that prevent their free exercise, which translates into the problem of solving how far such restrictions can be imposed in favor of the environment.

The answer for Bermúdez is that the provisions of regulation $19 \mathrm{~N}^{\circ} 8$ subsections 2 , establishes a constitutional mandate in favor of the environment in charge of the legislator, however for others such as a study considered the Constitution when protecting the environment is not done in a very decisive way, since only through the law would it be possible to restrict other rights, restrictions that must also be specific, so that it is precisely the rights with economic content that are hardly limited[17].

As for the property right, this may be limited because of the social function of property, and only through a law founded, either in the general interests of the nation, national security, public health, and conservation of the environmental heritage. Again, the environmental limitation of property rights is not so decided since it now uses the concept of conservation and not preservation, despite the scope already seen. 
Although it is not frequent, other rights could be restricted, among them the freedom to work and acquire all kinds of goods, except those that nature has made common to all men, these only in an exemplary way [18].

\section{Environmental constitutional reform}

From 2008 to 2018, six bills have been entered into the National Congress to reform the environmental issue in the Constitution. The six listed below will be reviewed, but with emphasis on the 06 of March 2018, because it proposes not a partial reform, but a new Constitution:

Bulletin 5730-07 of the 17 of January 2018, which seeks to modify the second paragraph of article 20 of the Political Constitution of the Republic in matters of origin of the protection resource regarding the right to live in a pollution-free environment. This is in process and was entered by motion.

Bulletin $6004-07$ of the 31 of July 2008, to modify the second paragraph of article 20 of the Political Constitution of the Republic, establishing that the environmental protection appeal has the character of popular action, in the terms indicated in-process and entered by motion.

Bulletin 7659-12 of the 17 of May 2011, draft constitutional reform related to plebiscites on environmental matters. It was archived and is not pending.

Bulletin 10486-07 of the 23 of December 2015, to reform the Constitution to create the Ombudsman for the environment in process and entered by motion.

Bulletin 11387-07 of the 16 of August 2017 incorporates the precautionary principle in regulating the right to live in a pollution-free environment. Entered by motion and pending.

Bulletin 11617-07 of the 06 of March 2018, Constitutional reform project, entered by presidential message.

Finally, three new projects have been presented. These are Bulletin 12653-07 of the year 2019, which establishes the duty of the state to protect the maritime spaces that it indicates to contribute to the care of the environment, Bulletin 12711-07 of 2019, which modifies the Fundamental Charter to establish the duty of the state to promote the development of smaller companies, whose production processes and products favor the use of non-conventional renewable energies, or promote a pollution-free environment, and finally, Bulletin 13206-07 of 2020, which modifies the Fundamental Charter to impose on the state the duty to promote and facilitate citizen participation and access to information for all people, in matters related to the environment.

\subsection{Modifications to the Protection Resource}

Currently, the protection remedy proceeds in favor of those who, due to arbitrary or illegal acts or omissions, suffer deprivation, disturbance, or threat in the legitimate exercise of the rights and guarantees that the Constitution establishes, however, the protection resource in favor of the Right to Living in a pollution-free environment is more limited. Only proceeds due to illegal acts or omissions, so Bulletin, 5730-07, tries to expand the field of its application so that it is also brought against arbitrary acts. It is known that even legal decisions can be arbitrary, undermining the right to a healthy environment.

During 2008, Bulletin 6004-07 was also presented, which, unlike the previous one, is based on the fact that for a long time, the environmental protection resource did not have broad active legitimacy, so this project intends to modify the second paragraph of Article 20 as follows:

In this case, the action may be filed by any person who resides in the commune where the action or omission that affects the right mentioned above occurs or by organizations whose field of action is aimed at the defense and preservation of the environment. 
Remembering that in practice, the criteria for active legitimation have been broadened, it would make no sense today to opt for the eclectic doctrine - of the adjacent environment - through this bill since it also limits the range of involvement at the local level.

\subsection{Plebiscites on environmental matters}

Bulletin 7659-12 seeks to introduce a new subsection to Article 19 No. 8, so that, in the face of large projects or activities likely to cause great environmental impact, a plebiscite can be called so that citizens can pronounce on whether they are in favor of a project or not, to ensure the right of the people and, on the other hand, to promote the duty of the state to protect the environment. Although it is archived and its processing is not ongoing, it is relevant and innovative, since if approved, this would be a strong tool for direct participation of citizens in environmental matters; however, it should be noted that Chile has little experience in plebiscites[18, 19].

On the other hand, Chile has an institution in charge of evaluating projects that cause environmental impact. This is the Environmental Assessment Service, a decentralized public body whose management evaluates each project by different competent public entities. Although it has shortcomings that deserve to be corrected, Said institutionality is the path that Chile chose and that it has been developing for a decade[20].

Some conflicts that arise with this project are: The geographical scope indicated for which environmental plebiscites would be considered would assimilate them to communal plebiscites, leaving aside intercommunity, and there are even projects that have a regional and interregional scope. Likewise, it does not consider a relevant factor or measure on which projects should be plebiscite so that it would imply submitting every project to two systems: environmental evaluation and plebiscites, without harmonizing both systems, and requiring large financing costs [21].

Plebiscites on environmental matters are not part of the already created environmental institutions. They could even be counterproductive, playing in favor of other rights and with significant and irreversible losses to the environment.

\subsection{An environmental Ombudsman}

This Bulletin, departing from the anthropocentric vision so far followed by Chile, is based on the deepening of the protection of the environment and the rights of nature. It is the same project that, citing jurisprudence of the Inter-American Court of Human Rights, maintains that "there is an undeniable relationship between the protection of the environment and the realization of other human rights" (Case of Kawas Fernández vs. Honduras, 2009, Considering 184), suggesting that:

nature, where life is reproduced and carried out, supposes respect by all people for their existence and maintenance and regeneration of their life cycles, functions, and evolutionary processes, (...) rethinking the question of the rights of non-human entities[20, 21].

Based on the preceding, this project proposes creating a body called Defense of the Environment, which deepens the state's duty to protect the environment with responsibility for future generations, promoting respect for all the elements that make up the ecosystem. And that in addition, in cases where there is a loss, decrease, or impairment to the environment or its components, it is prone to its repair.

Without modifying the provisions of article 19 No. 8, this project attempts to introduce a new chapter to the Constitution, one that gives rise to an autonomous body with legal personality under public law and its assets, which ensures both environmental rights and guarantees of the Political Constitution of the Republic, as well as international treaties in force and ratified by Chile, assuming this new institution the defense of the environment, in addition to urging the state to request advisory opinions from the Inter-American Court of Human Rights, concerning the application of treaties. 
Similarly, to protect people's rights, it is assigned a role in preparing recommendations, opinions, reports, and evaluations on national policies, and even contemplate mediation functions between affected people and institutions or companies responsible for the environmental disturbance.

Although there is no agreement on the fundamentals set out in the project, it can also constitute a favorable and effective tool for protecting the environment and people's rights, especially by facilitating access to environmental justice in environmental matters.

\subsection{Precautionary principle and article 19 No. 8 of the Constitution}

This project adds a new paragraph to Article 19 No. 8; the proposal is When there is a risk of serious or irreversible damage to the environment, the lack of scientific certainties should not be argued by the State bodies as a reason to postpone the adoption. Effective and efficient measures to prevent its degradation.

Currently, there is no legal norm that expressly includes the precautionary principle. However, likewise, the judiciary, hearing environmental issues, has resorted to principles of environmental law, thus, for example, in the 2019 judgment, the Supreme Court bases its decision through the precautionary principle and preventive measures as guiding elements, in attention to the lack of elements of judgment to determine the precise causes and effects of pollution episodes and given the urgency of protecting the fundamental rights of people (Various Appellants with private companies, State, various Public Institutions and the State of Chile, 2019, Considering 38 and 44) [22].

Although it should be noted that the above is not something common, and neither is the harmonization of International Treaties with current law. There is also a great delay in the internal implementation of the commitments and obligations acquired by Chile through International Law [23].

In this sense, the inclusion of the precautionary principle at the constitutional level would constitute a tool of unquestionable value in favor of the environment and people's rights, providing a guideline for the courts' actions in the resolution of controversies transversely for the state.

Finally, it should be noted that the precautionary principle has been expanded, and nowadays, it not only operates in the face of the risk of serious or irreversible damage but has also begun to demand a pattern of behavior, applicable across the entire Administration and society, promoting the integral protection of the environment under the expression of a dignified life [24]. This last aspect is not covered in the indicated project.

\subsection{Constitutional reform project}

This project was presented to the National Congress through the message of the President of the Republic of the time and not only tries to modify the environmental issue, but it is a total reform to the Constitution that arises from a long process in which the citizens by For the first time in the history of Chile, it participated in its first stage.

The Reform process considered three moments: the Encounter, the Deliberation, and the Sovereignty. The Meeting referred to the participatory phase and consisted of citizen participation at the local, provincial, and regional levels, a process with transparency, inclusion, and the absence of political bias. In this first stage, 204,402 people participated, Chileans or foreigners residing in Chile over 14 years of age. The Deliberation consists of the discussion on the constitutional contents in the headquarters of the National Congress. Finally, the last stage, Sovereignty characterized by a plebiscite ratifying the constitutional change. This project is in Congress, but the discussion around it has not yet taken place[22, 23].

\subsubsection{Citizen bases before the project}


The environmental issue was present in the discussion generated in the three levels that included citizen participation. Likewise, according to the participation figures reached, the Organization for Economic Cooperation and Development (2017) classified the process as successful[23], so it is interesting to look at how citizens' deliberated what was collected in the project.

The participatory stage was carried out during 2016 through individual electronic consultation and citizen dialogues, ending at the beginning of 2017 after special consultation with indigenous peoples. Then, with the observations made by the citizens, the results were systematized by a Committee created for this purpose, which produced a Report whose results were the input for the Government to prepare a draft of the new Constitution; the latter was presented on the 06 of March 2018.

According to the Executive Report of the Systematization Committee (2017) 21 of the citizen participation process, the following was obtained in environmental matters:

Scope of values and principles: The one that reached the greatest consensus was respect and conservation of nature or the environment, occupying fourth place in individual consultation; then the justice, equality, and democracy. In the local self-convened meetings (ELA), it held third place; in the provincial councils, it reached the fourth position; and fifth in the regional councils. In these instances, in general, the idea of environmental protection is affirmed as a foundation for life, and an allusion is made to conserve for future generations in harmony with sustainable development. In regional councils, it is even considered a Human Right[24].

Scope of rights: In the individual consultation, ELA, provincial and regional councils, the right to the environment is in sixth and seventh position. As a forced idea, the right to enjoy a healthy, pollution-free, and sustainable environment is proposed.

Scope of duties and responsibilities: In the individual consultation, ELA, provincial and regional councils, the environment had greater consensus, occupying the first and second place, and the possibility of its inclusion is considered as a duty of citizens[25].

\subsubsection{Approaches to the environment in the Draft Constitution}

The new Constitution project contemplates the right to the environment in the same terms as the 1980 constitutional text, but now in article 19, number 11, how the term "pollution-free environment" was seen leaves aside those violations that are not due to pollution cases. Although the term could be endowed with the same content as that of a "healthy," "adequate," "healthy" environment, among others, making them synonymous, the truth is that this vision of the environment, nor was what was expressed by citizens accepted. In this sense, a future project must include a Law that emphasizes that people enjoy an environment compatible with a healthy life and that broadens the idea that ecosystems have an ideal or favorable state in which it can be carried out and developed. Life in its many manifestations[26].

As for the term "ecologically balanced" or simply "balanced," they do not seem adequate since ecosystems, especially natural ones, are not static and are constantly subject to internal or external forces by which they try to adapt, without implying a balance; The term "safe environment" in turn would not be correct either, since it is difficult to speak of security in the case of natural or artificial ecosystems; and even more inappropriate may be the word "protected," which would lead to something even contrary to the sustainable development that the project intends[27-30].

The healthy expression environment has a broad consensus in other Constitutions. Still, following the literality, it would allude to a state that only links it to the environment itself, and indeed there are healthy environments, which could be unhealthy and incompatible with the life of the human being. In any case, a healthy, healthy, or adequate environment imposes a higher standard than the current one.

There is no proposal to modify the text of Article 19 No. 8 if pertinent innovations are observed that should be specified and distributed in other project provisions [31]. 
A first inclusion is in article 3, by which:

The state is at the service of the people, and its purpose is the common good, for which it must create the necessary conditions for the integral and sustainable development of the community and its members, fully respecting, and with fiscal responsibility, the rights and guarantees that this Constitution establishes [24, 25].

In turn, this article establishes the duties of the state, one of which is to create the necessary conditions for the integral and "sustainable" development of the community and its members. On the other hand, the protection of the environment and the historical and cultural heritage is added as a specific duty.

The addition of a special duty of the state regarding the protection of the environment in chapter I on Bases of Institutionality leaves behind the discussion about whether protecting the preservation of nature is a duty or only reflects the good intentions of the state by creating policies, programs and plans in favor of the environment[32-35].

Regarding the inclusion of sustainable development, this is a concept that reaches great consensus at the international level and is key to achieving the common good to which a State must strive [26], and which consists of the possibility of satisfying socialeconomic needs, of cultural diversity and a healthy environment of the present, without compromising the expectations of future generations.

In the citizen dialogue before the drafting of the project, the idea of conserving for future generations was raised so that, although it is implicitly possible, it is possible to make some connection to it with sustainable development.

The protection that the State grants to human rights and the environment through the direct protection of nature and its resources for future generations is key for the extension of life and the state. So, although the inclusion of sustainable development may be positive, an extensive interpretation should not be made in favor of future generations since the current interpretation of constitutional precepts is already concise; it is applied in the same way.

On the other hand, regarding the incorporation of sustainable development into a Constitution, the criticism arises that this may be unfavorable since development together with the rights paradigm creates a utopian framework of response to the environmental crisis, in which It is intended to keep the promise of better living conditions in terms of consumption capacity and a growing satisfaction of human needs. This model is deepening, without materializing, and that has not proven to have the transformative capacity, nor does it seem to promote regulatory innovations that address the problems and challenges that arise [27].

A second inclusion is present in article 4 of the project, which recognizes respect for the rights guaranteed in the Constitution and in international treaties ratified in Chile, making special mention of the Universal Declaration of Human Rights of 1948 and adding that the organs of the state must reconcile such rights with those of the Constitution, which constitutes a direct mandate to the judiciary for their application.

A Constitution largely defines the criteria by which the legislator must abide and the limits that judges must adhere to when applying current legislation [28], which should include international treaties as a source of law. The above would constitute significant progress.

The State of Chile has been active and participant in different instances in the international arena, 23 and if it aspires to become a developed State, it must seek sustainable ways to achieve this for the well-being of its population, incorporating what is contained in the treaties signed by Chile.

Regarding the limitations to property rights derived from its social function, the same conditions are described, that is, as required by the general interests of the nation, national security, public utility and health, and the conservation of environmental heritage, but the latter is modified to "the conservation of heritage and environmental sustainability" 24. 
It should be noted that this latest Bulletin presented faithfully collects what is expressed by the public, in that the protection of the environment does not correspond only to the state, but to every person, according to what is stated in Article 22 of the project, in which it is explicit that all people have to protect and conserve nature and the historical and cultural heritage.

Regarding the protection resource, it is stipulated in such a way that it does not distinguish between fundamental rights, since anyone who considers such rights injured could appeal for this, either by arbitrary or illegal acts, caused by any person or institution, be it private or public, -a situation not contemplated in the current Constitution-, however, omission cases of omission.

A fact that makes the difference between the appeal for protection in this draft Constitution derives from the possibility of filing in any ordinary court, and that, from what was resolved in the first instance, an appeal is no longer made to the Supreme Court, but to the Court Constitutional, which somehow completely changes the scheme so far established in the matter.

Although the latest reform bill entered standardizes the protection resource and opens it to the entire catalog of constitutional rights in Article 19, it leaves them to the ordinary courts, which is favorable in terms of access to justice; however, the objections regarding the preparation of ordinary court judges in environmental matters and the deficiencies of the current procedural system.

It is valid that both natural and legal persons can appeal for the guarantee. However, it must also be clarified that the protection action is contemplated against violations of fundamental rights, and therefore, it should not be used as a tool to protect the environment itself. The current Political Constitution of Chile does not establish collective actions in favor of the environment, and this is something that the New Constitution Project did not carry out, and that should be present in a 21st century Constitution. In this sense, there remains a great void, and that would make the need for special actions in favor of the direct protection of the environment much more evident, giving rise to the preventive principle that should govern in the matter.

\section{Conclusion}

After the brief tour of Environmental Constitutionalism in Latin America, which progressively and after the Stockholm Conference has been introduced in the Constitutions of the region's States, people's right to the environment is established. However, greater consensus reaches the terms right to a healthy and balanced environment. The Political Constitution of the Republic of Chile adhering to Environmental Constitutionalism with its article 19 No. 8 differs from other Latin American Constitutions in its wording since only in Chile is it alluded to a pollution-free environment. The said provision has not been modified since its establishment, and, as was made explicit, some aspects merit reformulation both by people and the environment, without thereby tending to a biocentric vision. Although some of the environmental reform projects contain favorable aspects, none propose another way of enshrining the law, nor do they propose substantial reforms alone or integral to the environmental question.

The project of an Environmental Defender is relevant for creating an autonomous body with a direct role in the protection of people's rights, as well as of the environment itself, intervening in risk situations and proposals for effective reparation when the damage has occurred. Likewise, the bill that introduces the precautionary principle deserves to be present in the debate, which being in express form would allow its direct application by the courts and all organs of the Administration. The last revised project proposes a total reform to the Constitution, and in general, it is positive in the environmental field, for having collected at least in part, some ideas raised in the citizen dialogue before its drafting, mainly regarding the duties shared by the state and people. The idea of extend- 
ing the environment to another chapter of the Constitution, such as the Bases of Institutionality, is beneficial since this is central to the following. Likewise, the incorporation of the special duty of protection by the state reinforces what is already present in the chapter on Rights and Duties, and the term sustainable development would at least be in harmony with what is advanced in the international arena and following the Declaration of Stockholm and Rio, as seen.

However, the text of the last revised Bulletin is still insufficient regarding other duties of the state, such as prevention, to tend to mitigate or repair in the case of damage, so that if negative environmental impacts or damage occur, interfere as little as possible with people's quality of life. The standard regarding the right to free from contamination is not exceeded, nor are actions taken to defend the environment itself. Conserving for future generations was omitted, which as a duty could drive the formulation of effective environmental policies, thus approaching to specify better environmental standards that are in harmony with human rights, especially the right of people to enjoy a Such an environment that allows the quality of life that citizens aspire to, making way for the common good that the Constitution intends.

Ultimately, strengthening the environmental issue at the constitutional level is key. And although one is in favor of a new Constitution, even with greater citizen participation, substantial improvements can also be made through partial reforms. It is essential to understand that the environment plays an essential role in life in its many manifestations, and therefore deserves special protection, which is not observed in constitutional reform projects. Almost forty years ago, a great step was taken by stimulating people's right to a pollution-free environment in the Political Constitution of the Republic of Chile. However, the passage of time has shown that the constitutional environmental issue requires better treatment. A Constitution must be an engine for the protection of fundamental rights and considering the need for a constitutional change in Chile personally, and it is also time to rethink the environmental issue and achieve a text decided to protect the rights of people and the environment. Finally, the elements raised here are worth keeping in mind given the current situation, direct a future and forthcoming Constitution for Chile.

\section{Supplementary Materials: “Not Applicable."}

Author Contributions: "Conceptualization, NN and AS; methodology, AS; software, EA; validation, EA, AS and NN; formal analysis, NN; investigation, NN; resources, AS; data curation, EA; writingoriginal draft preparation, NN; writing - review and editing, NN; visualization, NN; supervision, $\mathrm{NN}$; project administration, NN, All authors have read and agreed to the published version of the manuscript."

Funding: "This research received no external funding."

Data Availability Statement: “No related data."

Acknowledgments: “Not applicable."

Conflicts of Interest: "The authors declare no conflict of interest."

\section{References}

[1] Shaw, D.; Shiu, E. An assessment of ethical obligation and self-identity in ethical consumer decision-making: A structural equation modelling approach. Int. J. Consum. Stud. 2002, 26, 286-293.

[2] Goldsmith, E.; Goldsmith, R. Social influence and sustainability in households. Int. J. Consum. Stud. 2011, 35, 117-121.

[3] Organización de Consumidores y Usuarios. Otro Consumo Para un Futuro Mejor. Madrid: Organización de Consumidores y Usuarios (OCU) y el Foro de Nueva Economía. Available online: https:/www.ocu.org/-/media/ocu/resources/themes/consumo $\% 20 \mathrm{y} \% 20$ familia/no\%20center\%20of $\% 20$ content/dossiers/otroconsumoparaunfuturomejor-informe.pdf?rev=1b58dbdd-2f04-4e8e-8c72-80de595cfe2f\&la=es-es (accessed on 16 December 2019).

[4] Carbonell, M. Eficacia de la Constitución y Derechos Sociales. Estud. Const. 2008, 6, 43-71.

[5] Luque, A.; Herrero-García, N. How corporate social (ir) responsibility in the textile sector is defined, and its impact on ethical sustainability: An analysis of 133 concepts. Corp. Soc. Responsib. Environ. Manag. 2019, 26, 1285-1306. 
[6] Bárcena, A. América Latina ha Perdido el Tren de la Política Industrial y la Innovación. Available online: https:/elpais.com/economia/2020/02/05/actualidad/1580921046_527634.html (accessed on 8 February 2020).

[7] Beck, U. La Sociedad del Riesgo; Paidós: Barcelona, Spain, 2008.

[8] Luque, A.; Jiménez-Sánchez, A. Textile sustainability processes: Success, or a new way to contaminate under a friendly paradigm. J. Incl. 2018, 6, 259-288.

[9] World Meteorological Organization. WMO Greenhouse Gas Bulletin. The State of Greenhouse Gases in the Atmosphere Based on Global Observations through 2018. Available online: ane4bf-datap1.s3-eu-west-1.amazonaws.com/wmocms/s3fspublic/ckeditor/files/GHG-Bulletin-15_en.pdf?mQP5SDxBr_pHsQNJsAPrF8E5XnqkfHo2 (accessed on the 16 of February 2020).

[10] Landrigan, P.; Fuller, R.; Adeyi, O.; Arnold, R.; Basu, N.; Bibi, A.; Coll-Seck, A. The Lancet Commission on pollution and health. Lancet 2018, 391, 462-512. Available online: http://www.thelancet.com/journals/lancet/article/PIIS01406736(17)32345-0/fulltex (accessed on the 08 of February 2020).

[11] Barroso, F. La responsabilidad social empresarial: Un estudio en cuarenta empresas de la ciudad de Mérida, Yucatán. Contaduría y Adm. 2008, 226, 73-91.

[12] Gilli, J. Responsabilidad social. Revista Visión de Futuro 2006, 5, 1-18.

[13] Rivera, T. Lo ocurrido en Chile alerta que el PIB no lo es todo. Espinosa, J. Interviewer. Available online: https://www.elmundo.es/internacional/2019/12/11/5df019d6fdddffcc128b468c.html (accessed on the 15 of November 2019).

[14] Wolff, J. Business Power and the Politics of Postneoliberalism: Relations between Governments and Economic Elites in Bolivia and Ecuador. Lat. Am. Politics Soc. 2016, 58, 124-147.

[15] Passet, R. Las Grandes Representaciones del Mundo y la Economía a lo Largo de la Historia: Del Universo Mágico al Torbellino Creador; Clave Intellectual: Madrid, Spain, 2013.

[16] Gregor, C. Nuevas narrativas constitucionales en Bolivia y Ecuador: El buen vivir y los derechos de la naturaleza. Latinoamérica. Rev. Estud. Latinoam. 2014, 2, 9-40.

[17] Radcliffe, S.A. Development for a postneoliberal era? Sumak kawsay, living well and the limits to decolonisation in Ecuador. Geoforum 2012, 43, 240-249.

[18] García, D. Doctrina constitucional peruana en el siglo XX. Hist. Const. 2010, 11, 507-511.

[19] Figueiredo, M. La evolución político-constitucional de Brasil. Estudios Const. 2018, 6, 209-246.

[20] Rouquié, A. América Latina: Introducción al Extremo Occidente; Siglo XXI: Mexico City, Mexico, 1989.

[21] Herrera, J. Las cláusulas de integración en las constituciones de Suramérica: 200 años después de la Carta de Jamaica. Rev. Colomb. Int. 2016, 86, 8-12.

[22] Sánchez, R. La trascendencia del constitucionalismo social en América Latina. Cuest. Const. 2012, 27, $251-309$.

[23] Häberle, P. La Libertad Fundamental en el Estado Constitucional; Fondo Editorial PUCP: San Miguel, Peru, 1997.

[24] Pérez Royo, J. El Fracaso de la Constitución. Available online: https://www.eldiario.es/contracorriente/fracaso-constitucion_6_948465156.html (accessed on 17 January 2019).

[25] Llorent, V.; Llorent, M. La Educación en las Constituciones de los Países del Cono Sur Americano. Ensaio Aval. Pol. Públ. Educ. 2015, 23, 293-310.

[26] Nogueira, H. Los Derechos Económicos, Sociales y Culturales como Derechos Fundametales Efectivos en el Constitucionalismo Democrático Latinoamericano. Estud. Const. 2009, 7, 143-205.

[27] International Labour Organization. Igualdad de Género en América Latina y el Caribe. Available online: https://www.ilo.org/americas/temas/igualdad-de-g\%C3\%A9nero/lang--es/index.htm (accessed on 14 November 2019).

[28] Political Constitution of Honduras. Available online: https://www.oas.org/dil/esp/constitucion_de_honduras.pdf (accessed on the 14 of December 2019).

[29] United Nations Economic Commission for Latin America and the Caribbean. Atlas migración en los países del Norte de Centroamérica. Santiago: Centro Latinoamericano y Caribeño de Demografía (CELADE). Available online: https://t.co/ixSlu7n8h5?amp=1 (accessed on 14 October 2019).

[30] Political Constitution of Chile. Available online: https://www.camara.cl/camara/doc/leyes_normas/constitucion_politica.pdf (accessed on the 24 of December 2019).

[31] Luque, A.; de Pablos, C. Factors that promote the lack of ethics in the production and logistics practices of transnational companies. Lan Harremanak 2016, 34, 336-370.

[32] Newman, M. Networks; Oxford University Press: Oxford, UK, 2018.

[33] Csardi, G.; Nepusz, T. The igraph software package for complex network research. Int. J. Complex. Syst. 2006, 1695, 1-9.

[34] Caïs, J. Metodología del Análisis Comparative; Centro de Investigaciones Sociológicas: Madrid, Spain, 1997.

[35] Aguilar, G.; LaFosse, S.; Rojas, H.; Steward, R. Análisis comparado del reconocimiento constitucional de los pueblos indígenas en América Latina. Versión resumida del artículo "The Constitutional Recognition of Indigenous Peoples in Latin America". Pace Int. Law Rev. Companion 2010, 2, 1-15. 